\title{
Front Matter: Volume 7243
}

, "Front Matter: Volume 7243," Proc. SPIE 7243, Visualization and Data Analysis 2009, 724301 (20 January 2009); doi: 10.1117/12.822313

SPIE Event: IS\&T/SPIE Electronic Imaging, 2009, San Jose, California, United SPIE. States 


\title{
PROCEEDINGS \\ IS\&T/SPIE \\ Electronio \\ Imeging \\ Science and Technology
}

\section{Visualization and Data Analysis 2009}

\author{
Katy Börner \\ Jinah Park \\ Editors \\ Matti T. Gröhn \\ Ming C. Hao \\ Jonathan C. Roberts \\ Pak Chung Wong \\ Co-Editors
}

19-20 January 2009

San Jose, California, USA

Sponsored and Published by

IS\&T-The Society for Imaging Science and Technology

SPIE

Cosponsored by

Hewlett-Packard Company (United States) 
The papers included in this volume were part of the technical conference cited on the cover and title page. Papers were selected and subject to review by the editors and conference program committee. Some conference presentations may not be available for publication. The papers published in these proceedings reflect the work and thoughts of the authors and are published herein as submitted. The publishers are not responsible for the validity of the information or for any outcomes resulting from reliance thereon.

Please use the following format to cite material from this book:

Author(s), "Title of Paper," in Visualization and Data Analysis 2009, edited by Katy Börner, Jinah Park, Proceedings of SPIE-IS\&T Electronic Imaging, SPIE Vol. 7243, Article CID Number (2009).

ISSN 0277-786X

ISBN 9780819474933

Copublished by

SPIE

P.O. Box 10, Bellingham, Washington 98227-0010 USA

Telephone +1 3606763290 (Pacific Time) · Fax +1 3606471445

SPIE.org

and

IS\&T-The Society for Imaging Science and Technology

7003 Kilworth Lane, Springfield, Virginia, 22151 USA

Telephone +1 7036429090 (Eastern Time) · Fax +1 7036429094

imaging.org

Copyright (c) 2009, Society of Photo-Optical Instrumentation Engineers and The Society for Imaging Science and Technology.

Copying of material in this book for internal or personal use, or for the internal or personal use of specific clients, beyond the fair use provisions granted by the U.S. Copyright Law is authorized by the publishers subject to payment of copying fees. The Transactional Reporting Service base fee for this volume is $\$ 18.00$ per article (or portion thereof), which should be paid directly to the Copyright Clearance Center (CCC), 222 Rosewood Drive, Danvers, MA 01923. Payment may also be made electronically through CCC Online at copyright.com. Other copying for republication, resale, advertising or promotion, or any form of systematic or multiple reproduction of any material in this book is prohibited except with permission in writing from the publisher. The CCC fee code is 0277-786X/09/ $\$ 18.00$.

Printed in the United States of America.

Paper Numbering: Proceedings of SPIE follow an e-First publication model, with papers published first online and then in print and on CD-ROM. Papers are published as they are submitted and meet publication criteria. A unique, consistent, permanent citation identifier (CID) number is assigned to each article at the time of the first publication. Utilization of CIDs allows articles to be fully citable as soon they are published online, and connects the same identifier to all online, print, and electronic versions of the publication. SPIE uses a six-digit CID article numbering system in which:

- The first four digits correspond to the SPIE volume number.

- The last two digits indicate publication order within the volume using a Base 36 numbering system employing both numerals and letters. These two-number sets start with 00, 01, 02, 03, 04, 05 , 06, 07, 08, 09, OA, OB ... 0Z, followed by 10-1Z, 20-2Z, etc.

The CID number appears on each page of the manuscript. The complete citation is used on the first page, and an abbreviated version on subsequent pages. Numbers in the index correspond to the last two digits of the six-digit CID number. 


\title{
Contents
}

\author{
$\checkmark$ Conference Committee \\ vii Introduction
}

SESSION 1 VISUALIZING MIND AND BODY: BIOINFORMATIC APPLICATIONS

724303 Analytics for massive heat maps [7243-02]

S. Bohn, D. Payne, G. Nakamura, D. Love, Pacific Northwest National Lab. (United States)

724304 Asymmetry analysis based on genetic algorithms for the prediction of foot ulcers [7243-03] N. Kaabouch, Y. Chen, J. Anderson, F. Ames, Univ. of North Dakota (United States);

R. Paulson, Altru Wound Clinic (United States)

724305 Computer assisted analysis of microscopy images [7243-04]

M. Sawicki, P. Munhutu, J. DaPonte, C. Caragianis-Broadbridge, Southern Connecticut State Univ. (United States); A. Lehman, Trinity College (United States) and Southern Connecticut State Univ. (United States); T. Sadowski, E. Garcia, C. Heyden, L. Mirabelle,

P. Benjamin, Southern Connecticut State Univ. (United States)

724306 Visualizing conserved gene location across microbe genomes [7243-05]

C. D. Shaw, Simon Fraser Univ. (Canada)

\section{SESSION 2 VISUALIZING INTERNAL AND EXTERNAL SPACES: GEOGRAPHIC, SEMANTIC, SCIENTIFIC}

724307 Teaching children the structure of science [7243-06]

K. Börner, F. Palmer, J. M. Davis, E. Hardy, Indiana Univ. (United States); S. M. Uzzo, The New York Hall of Science (United States); B. J. Hook, Consultant, Indiana Univ. (United States)

724308 An adaptive spread spectrum (SS) synchronous data hiding strategy for scalable 3D terrain visualization [7243-07]

K. Hayat, LIRMM, Univ. of Montpellier II, CNRS (France); W. Puech, LIRMM, Univ. of Montpellier II, CNRS (France) and Univ. of Nimes (France); G. Gesquière, LSIS, Univ. of Marseille, CNRS (France)

724309 TGD: visual data exploration of temporal graph data [7243-08] M. Farrugia, A. Quigley, Univ. College Dublin (Ireland)

7243 OA Musician Map: visualizing music collaborations over time [7243-09] J.-D. Yim, C. D. Shaw, L. Bartram, Simon Fraser Univ. (Canada)

7243 OB Visual analytics of anomaly detection in large data streams [7243-10] M. C. Hao, U. Dayal, Hewlett-Packard Labs. Palo Alto (United States); D. A. Keim, Univ. of Konstanz (Germany); R. K. Sharma, A. Mehta, Hewlett-Packard Labs. Palo Alto (United States) 
7243 OC Understanding outside collaborations of the Chinese Academy of Sciences using Jensen-Shannon divergence [7243-11]

R. Duhon, Indiana Univ. (United States)

\section{SESSION 3 VISUALIZING TO EXPLICATE: ORGANIZATION, INFORMATION RESOURCES, SCIENTIFIC} DISCOVERY I

7243 OE A graphical environment for interactive four-dimensional data navigation [7243-14]

D. R. Wilding, R. P. Burton, Brigham Young Univ. (United States)

7243 OF Brainframe: a knowledge visualization system for the neurosciences [7243-15]

S. J. Barnes, Simon Fraser Univ. (Canada and Univ. of British Columbia (Canada);

C. D. Shaw, Simon Fraser Univ. (Canada)

7243 OG A main path domain map as digital library interface [7243-16]

J. Demaine, National Research Council (Canada)

$7243 \mathrm{OH} \quad$ A unified toolkit for information and scientific visualization [7243-17]

B. Wylie, Sandia National Labs. (United States); J. Baumes, Kitware, Inc. (United States)

SESSION 4 VISUALIZING TO EXPLICATE: ORGANIZATION, INFORMATION RESOURCES, SCIENTIFIC DISCOVERY II

7243 Ol Progressive refinement: more than a means to overcome limited bandwidth [7243-19]

R. Rosenbaum, H. Schumann, Univ. Rostock (Germany)

$72430 \mathrm{~J} \quad$ Visually comparing multiple partitions of data with applications to clustering [7243-20]

J. Zhou, S. Konecni, G. Grinstein, Univ. of Massachusetts, Lowell (United States)

7243 OK Uncertainty visualization in the Vislt visualization environment [7243-21]

A. Foulks, R. D. Bergeron, Univ. of New Hampshire (United States)

7243 OL Reservoir Model Information System: REMIS [7243-22]

S. Y. Lee, K.-W. Lee, T. Rhee, U. Neumann, Univ. of Southern California (United States)

7243 OM Multiresolution data aggregation for analytical exploration of large relational data [7243-23] M. Sanver, New York Institute of Technology, Abu Dhabi (United Arab Emirates); L. Yang, Western Michigan Univ. (United States)

Author Index 


\title{
Conference Committee
}

\author{
Symposium Chairs
}

Nitin Sampat, Rochester Institute of Technology (United States)

Jan P. Allebach, Purdue University (United States)

\section{Conference Chairs}

Katy Börner, Indiana University (United States)

Jinah Park, Information and Communications University (Korea,

Republic of)

\section{Conference Cochairs}

Matti T. Gröhn, Center for Scientific Computing (Finland)

Ming C. Hao, Hewlett-Packard Laboratories (United States)

Jonathan C. Roberts, Bangor University (United Kingdom)

Pak Chung Wong, Pacific Northwest National Laboratory (United States)

\section{Program Committee}

Uwe Brinkschulte, Universität Karlsruhe (Germany)

Paul Craig, Napier University (United Kingdom)

Steve Eick, Visual Insights (United States)

Robert F. Erbacher, Utah State University (United States)

Zhanping Liu, Mississippi State University (United States)

Joerg Meyer, University of California, Irvine (United States)

Hans-Georg Pagendarm, Deutsches Zentrum für Luft- und Raumfahrt e.V. (Germany)

Alex T. Pang, University of California, Santa Cruz (United States)

Aaron J. Quigley, University College Dublin (Ireland)

Deborah E. Silver, Rutgers University (United States)

Kalpathi R. Subramanian, The University of North Carolina at Charlotte (United States)

Yinlong Sun, Purdue University (United States)

J. Edward Swan II, Naval Research Laboratory (United States)

Yingcai Xiao, University of Akron (United States)

William J. Yurcik, University of Illinois at Urbana-Champaign (United States) 
Downloaded From: https://www.spiedigitallibrary.org/conference-proceedings-of-spie on 25 Apr 2023

Terms of Use: https://www.spiedigitallibrary.org/terms-of-use 


\section{Introduction}

Welcome to the proceedings of the Visualization and Data Analysis 2009 conference, now on its $16^{\text {th }}$ year. This onsite proceedings volume showcases the enormous diversity of research in topics such as

- Internet imaging, medical imaging, image processing

- Biomedical visualization and applications

- Internet, web, and security visualizations

- Analysis techniques and data mining

- Data exploration using classical and novel approaches

- Databases and visualization

- High-performance computing and parallel rendering

- Tools and applications exemplified by case studies

- Virtual environments and data visualization

- Information and scientific visualization

- Volume and flow visualization

- Interaction paradigms and human factors

This year's conference features 16 full papers and five short papers. Papers are grouped into three main sessions, titled

Visualizing Mind and Body: Bioinformatics Applications

Visualizing Internal and External Spaces: Geographic, Semantic, Scientific

Visualizing to Explicate: Organization, Information Resources, Scientific Discovery

Dr. Marc A. Smith, Chief Social Scientist for the Telligent Corporation will give this year's invited talk on "Visualizing Roles in Social Media". The talk will review his work on the impact of social networks on collective knowledge and value creation.

We would like to thank the 58 external reviewers and program committee members. Their expert reviews and evaluation of the submitted papers are essential for ensuring high quality papers and presentations. Mark A. Price served as an assistant to the Conference chairs and his patience and diligence was instrumental for the review process and the scheduling of VDA 2009.

It is the diversity of attendees and their works that sets this conference and associated proceedings apart from other visualization conferences. Within this proceedings volume you will find papers across the board from computer graphics to image processing, information visualization and scientific visualization. Few conferences can offer such a diverse and insightful inspection and cross-fertilization of the ongoing research throughout the field of visualization. We hope you enjoy these papers and we hope to see you at future conferences.

Katy Börner Jinah Park 
Downloaded From: https://www.spiedigitallibrary.org/conference-proceedings-of-spie on 25 Apr 2023

Terms of Use: https://www.spiedigitallibrary.org/terms-of-use 